\title{
Enhancement of Human Prolactin Synthesis by Sodium Butyrate Addition to Serum-Free CHO Cell Culture
}

\author{
Herbert Rodrigues Goulart, Fernanda dos Santos Arthuso, Marcos Vinicius Nucci Capone, \\ Taís Lima de Oliveira, Paolo Bartolini, and Carlos Roberto Jorge Soares
}

Biotechnology Department, IPEN-CNEN, Cidade Universitária, Avenida Professor Lineu Prestes 2242,
05508-900 São Paulo, SP, Brazil

Correspondence should be addressed to Carlos Roberto Jorge Soares, crsoares@ipen.br

Received 28 October 2009; Revised 9 February 2010; Accepted 1 April 2010

Academic Editor: Yujun George Zheng

Copyright ( $\odot 2010$ Herbert Rodrigues Goulart et al. This is an open access article distributed under the Creative Commons Attribution License, which permits unrestricted use, distribution, and reproduction in any medium, provided the original work is properly cited.

\begin{abstract}
Sodium butyrate $(\mathrm{NaBu})$ has been used as a productivity enhancer for the synthesis of recombinant proteins in Chinese hamster ovary $(\mathrm{CHO})$ cells. Thus, the influence of $\mathrm{NaBu}$ on the production of recombinant human prolactin (hPRL) from CHO cells was investigated for the first time. $\mathrm{CHO}$ cell cultures were submitted to a treatment with different concentrations of $\mathrm{NaBu}(0.25$ to $4 \mathrm{mM}$ ). Quantitative and qualitative analyses by reverse-phase high-performance liquid chromatography (RP-HPLC) and Western blot or SDS-PAGE, carried out directly on CHO-conditioned medium, showed that the highest hPRL expression was obtained with $1 \mathrm{mM} \mathrm{NaBu}$. In vitro biological assays based on noble rat lymphoma (Nb2) and mouse pro-B lymphoma (Ba/F3-LLP) cells were carried out on purified hPRL. Its bioactivity in the presence of $\mathrm{NaBu}$ was not apparently different from that of the First International Reference Reagent of recombinant hPRL (WHO 97/714). Our results show that NaBu increased the synthesis of recombinant hPRL in $\mathrm{CHO}$ cells, apparently without compromising either its structure or function.
\end{abstract}

\section{Introduction}

Human prolactin (hPRL), a $23 \mathrm{kDa}$ polypeptide hormone with a single chain of 199 residues, is a member of the family of cytokines, which includes erythropoietin, interleukin6 , and many others, but is most closely related, both evolutionarily and functionally, to human growth hormone and placental lactogen [1]. This polypeptide is known to be involved in a variety of actions [2], more than all the other pituitary hormones combined, such as cell proliferation, growth and development, water and electrolyte balance, and several physiological and behavioral aspects of mammal, bird, and reptile reproduction [3]. In humans, prolactin is secreted by pituitary lactotrophs under hypothalamic regulation. It circulates in the bloodstream and acts distally as an endocrine hormone. Apart from the pituitary, many extrapituitary sites for hPRL synthesis have been documented, including breast, prostate, and female reproductive tract, where it appears to act locally to regulate cellular growth and differentiation $[1,4,5]$. The hPRL gene has been cloned and the authentic form of the hormone efficiently expressed in bacterial periplasm and in Chinese hamster ovary $(\mathrm{CHO})$ cells in our laboratory [6-8]. Since hPRL is one of the hormones most frequently determined in routine clinical assays and several therapeutic applications are being considered, an increasing need for pure bioactive hPRL can be anticipated $[9,10]$.

Sodium butyrate $(\mathrm{NaBu})$ is a short chain fatty acid, originally identified as a product of anaerobic bacterial fermentation, which has been shown to alter the structure of chromatin in the nucleus of mammalian cells by reducing the activity of histone deacetylase [11]. One of the possible causes for improved gene expression by $\mathrm{NaBu}$ cells is histone hyperacetylation, which facilitates the access of general transcription factors in eukaryotic cells $[12,13]$. However, $\mathrm{NaBu}$ can also cause a cellular arrest, leading to increased apoptosis and resulting in an overall reduction in recombinant protein production over longer periods of time [14]. 


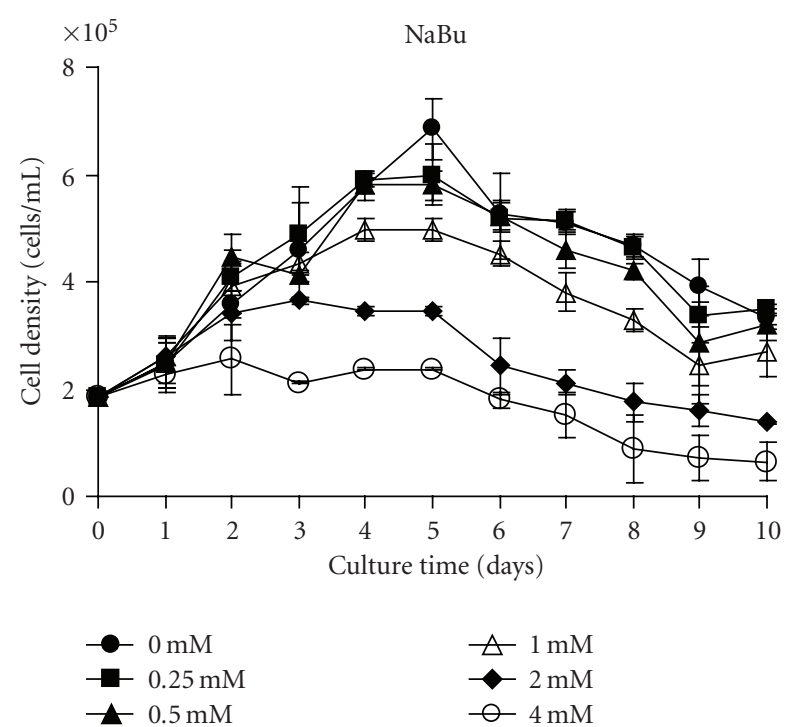

(a)

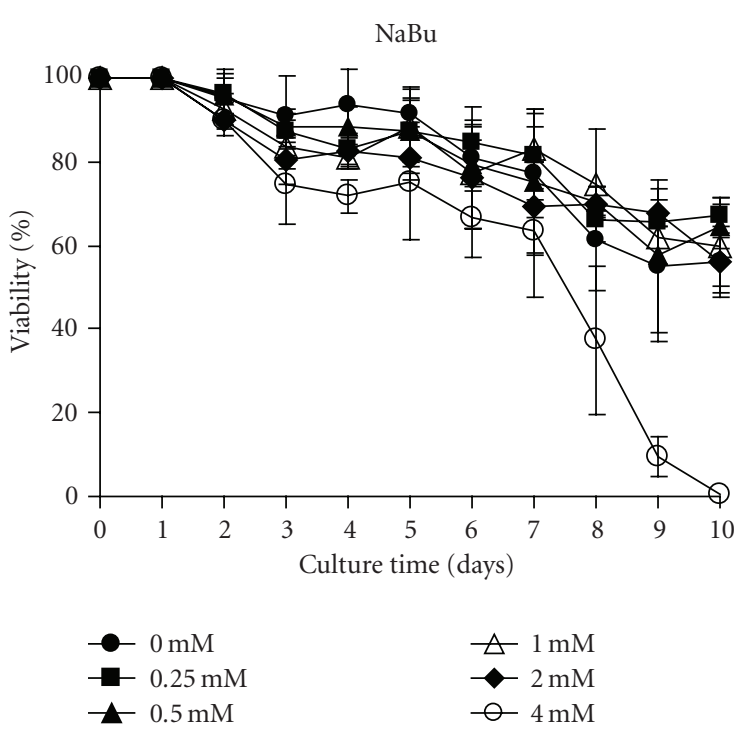

(b)

FIGURE 1: NaBu influence on cellular growth and viability of hPRL-secreting CHO cells. (a) Cellular growth and (b) cellular viability in a 10day hPRL production period under different $\mathrm{NaBu}$ concentrations. The cell viability was determined by the trypan blue exclusion procedure, following trypsinization. Values are the mean of two independent determinations.

$\mathrm{NaBu}$ treatment has been shown, via immunoassay determination, to increase the expression levels of foreign proteins such as human thrombopoietin, interferon- $\beta$-1a, and chimeric IgG3 antibodies in $\mathrm{CHO}$ cell cultures [15-17] by factors of 2-, 2.5-, and 3.6-fold, respectively, relative to nontreated cells. This led us to investigate, for the first time, via physicochemical techniques, whether addition of $\mathrm{NaBu}$ would also increase hPRL production in these cell cultures. In order to characterize the product obtained, we took advantage of a specific RP-HPLC methodology previously developed in our laboratory [18], which permits qualitative and quantitative analysis of hPRL directly in $\mathrm{CHO}$-conditioned medium. High-Performance Size-Exclusion Chromatography (HPSEC) methodology was used for both analytical and preparative purposes [19] and also allowed us to evaluated hPRL activity directly in two bioassays, after its purification from $\mathrm{CHO}$-conditioned medium [9].

\section{Materials and Methods}

2.1. Cell Culture. The clone expressing hPRL, derived from $\mathrm{CHO} \mathrm{dhfr}^{-}$cells (DUKX-B11) that had been transfected with the vector pEDdc-hPRL, was obtained in our laboratory [8]. Cells were thawed into T-flasks $\left(75 \mathrm{~cm}^{2}\right.$, from Corning Costar Corporation, Cambridge, MA) containing $\alpha$-minimal essential medium $(\alpha$-MEM, Gibco-Invitrogen Corporation, Grand Island, NY, USA) with L-glutamine and without ribonucleosides and deoxyribonucleosides, supplemented with $10 \%$ dialysed fetal bovine serum (dFBS), $40 \mu \mathrm{g} / \mathrm{mL}$ gentamycin, $4 \mathrm{~g} / \mathrm{L}$ glucose, and $100 \mathrm{nM}$ methotrexate. Cultures were maintained in a humidified incubator at $37^{\circ} \mathrm{C}$ in the presence of $5 \% \mathrm{CO}_{2}$.

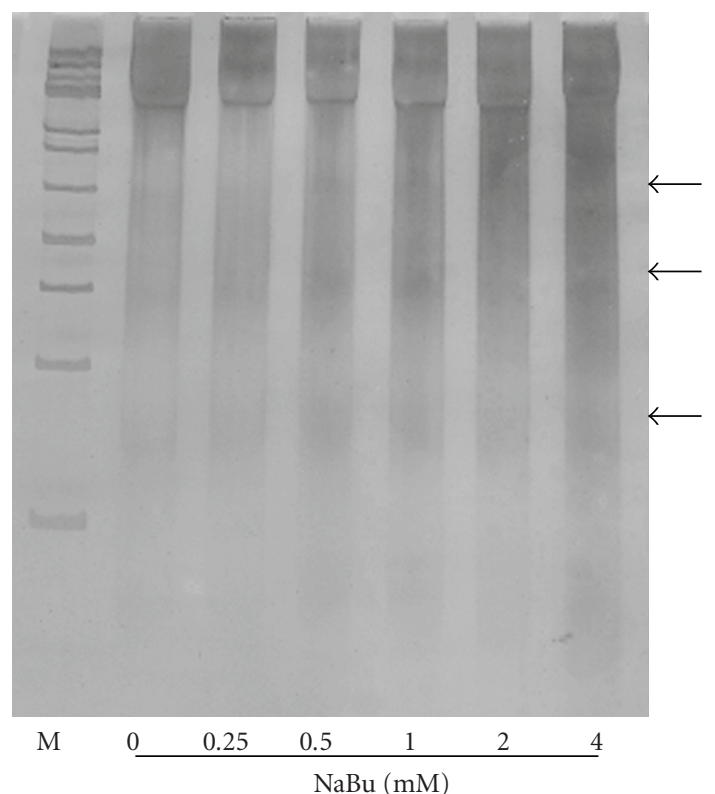

FIgURE 2: Electrophoretic patterns of DNA isolated from $\mathrm{NaBu}-$ treated and untreated $\mathrm{CHO}$ cells. Isolated chromosomal DNA $(2 \mu \mathrm{g})$ was electrophoresed on $5 \%$ polyacrylamide gel and intact and fragmented DNA bands were revealed by silver staining. Arrowheads designate DNA ladder formation. M: molecular weight marker, 100-bp DNA ladder. DNAs were isolated from day 8 cultures exposed to different concentrations of Nabu.

2.2. $\mathrm{NaBu}$ Treatment. $100 \mathrm{mM} \mathrm{NaBu}$ was prepared in phosphate-buffered saline (PBS) $\left(0.007 \mathrm{M} \mathrm{Na}_{2} \mathrm{HPO}_{4}, 0.01 \mathrm{M}\right.$ $\mathrm{NaH}_{2} \mathrm{PO}_{4}$, pH 7.4 and $0.15 \mathrm{M} \mathrm{NaCl}$ ), sterilized by passing 


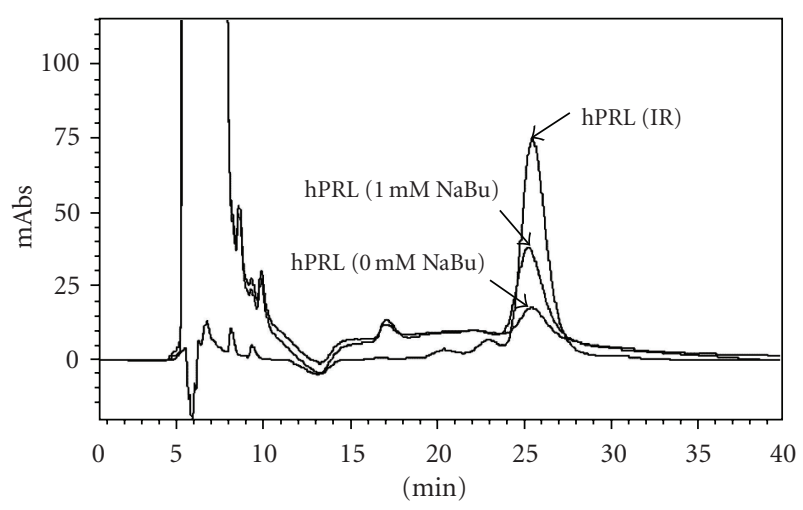

FIGURE 3: Overlay of RP-HPLC qualitative and quantitative analyses of hPRL secreted by $\mathrm{CHO}$ cells treated with different concentrations of $\mathrm{NaBu}$. IR: Internal Reference Preparation of periplasmic E. coliderived hPRL $(7.0 \mu \mathrm{g})$. mAbs: milliabsorbance.

through a $0.20 \mu \mathrm{m}$ syringe filter (Corning Incorporated, Corning, NY, USA), and stored in aliquots at $-20^{\circ} \mathrm{C}$. To examine the effect of different concentrations of $\mathrm{NaBu}$ on hPRL production, $1 \mathrm{~mL}$ of $\mathrm{CHO}$ cell suspension $(5 \times$ $10^{4}$ cells $/ \mathrm{mL}$ ) was seeded into each well of a 24 -well plate to obtain a concentration of $2 \times 10^{5}$ cells $/ \mathrm{mL}$. Cultures were then rinsed twice in PBS to remove serum and medium. Fresh medium was then added containing $\mathrm{NaBu}$ to a final concentration between 0 and $4 \mathrm{mM}$. Cells were grown for 10 days and $\mathrm{CHO}$ cell-conditioned medium was collected daily and stored at $-80^{\circ} \mathrm{C}$ for subsequent RP-HPLC or Western blot analysis.

For product purification, $\mathrm{CHO}$ cells were expanded into ten T-flasks, in $\alpha$-MEM supplemented with dFBS, until they were confluent. Cultures also were rinsed twice in PBS to remove serum and medium. When the cell density was $\sim 2 \times 10^{5}$ cells $/ \mathrm{mL}$, fresh medium was then added to the T-flasks: five contained no $\mathrm{NaBu}$, while the chosen amounts of $\mathrm{NaBu}$ were added to the other five. The hPRL-secreting confluent cultures were then maintained for up to ten days by replacing the medium every 24 hours. The conditioned medium was collected and stored, as mentioned above, for SP-Sepharose Fast Flow and HPSEC purification.

2.3. Cell Counts. To examine the effect of different concentrations of $\mathrm{NaBu}$ on cell density and viability, $1 \mathrm{~mL}$ of CHO cell suspension $\left(5 \times 10^{4}\right.$ cells $\left./ \mathrm{mL}\right)$ was seeded into each well of a 24-well plate to obtain a concentration of $2 \times 10^{5}$ cells $/ \mathrm{mL}$. NaBu was added to a final concentration between 0 and $4 \mathrm{mM}$ and cells were grown for 10 days, as mentioned above. Every 24 hours a sample for the different concentrations of $\mathrm{NaBu}$ was detached from 24well plate by treatment with $0.025 \%$ trypsin-EDTA in PBS. Total cell number and viability were determined by using the Trypan blue (Gibco-Invitrogen Corporation) exclusion method via haemocytometry and phase contrast microscopy, to distinguish viable and nonviable cells on the basis of dye uptake [20].

2.4. DNA Fragmentation Assay by Electrophoresis. $5 \times$ $10^{4}$ cells $/ \mathrm{mL}$ cells were seeded in 24 -well plate, treated and detached at regular times, as mentioned above. $1 \times$ $10^{6}$ cells $/ \mathrm{mL}$ per sample were lysed in $400 \mu \mathrm{L}$ of lysis buffer (50 mM Tris, $10 \mathrm{mM}$ EDTA pH 8.0, 1\% SDS) and $500 \mu \mathrm{g} / \mathrm{mL}$ proteinase K (Fermentas, Life Sciences, São Paulo, Brazil) at $37^{\circ} \mathrm{C}$ for 16 hours. The lysates were extracted with phenol: clorophorm: isoamylalcohol $(25: 24: 1)$. DNA was precipitated with $100 \%$ ice-cold ethanol. The resulting pellets of DNA were resuspended in TE buffer ( $\mathrm{pH}$ 8.0) [14] and treated with $10 \mu \mathrm{g} / \mathrm{mL}$ RNase A (Fermentas, Life Sciences, Brazil) prior to electrophoresis on a 5\% polyacrylamide gel at $70 \mathrm{~V}$ [21]. Intact and fragmented DNA bands were revealed by silver staining.

2.5. Gel Electrophoresis and Western Blot Analysis. Discontinuous SDS-PAGE, based on $15 \%$ polyacrylamide gels, was carried out under nonreducing conditions as described by Laemmli [22]. Proteins were revealed by silver or Coomassie brilliant blue G-250 (USB, Cleveland, OH) staining. The molecular mass markers were purchased from GE Healthcare Bio-Science Corp. (Piscataway, NJ, USA). Western blot analysis was performed according to Bannerman et al. [23], using ${ }^{125}$ I-labelled protein A [24] and anti-hPRL antiserum obtained in rabbit and validated in our laboratory against the NIDDK-anti-hPRL-3 from National Hormone and Pituitary Program, Torrance, CA, USA $[7,8]$.

2.6. Protein Determination. Total protein content was determinate by BCA protein assay, using bicinchoninic acid (Micro BCA protein assay kit, Pierce, Rockford, IL, USA). Pure bovine serum albumin (BSA, Sigma, São Paulo, Brazil) was used as standard.

\subsection{Reversed-Phase High-Performance Liquid Chromatogra-} phy (RP-HPLC). After the treatment with different $\mathrm{NaBu}$ concentrations, an aliquot of conditioned culture medium $(\sim 10 \mathrm{~mL})$ was concentrated ( $\sim 10$ fold) by using a centrifugal membrane filter Ultra 4 (Amicon, Millipore Corporation, Billerica, MA, USA) and applied to a RP-HPLC column. A Shimadzu Model SCL-10A HPLC apparatus coupled to a SPD-10AV UV detector (Shimadzu, MD, USA) was used, employing the Class VP software, also from Shimadzu. The column was a C4 Vydac 214TP54 $(25 \mathrm{~cm} \times 4.6 \mathrm{~mm}$ id, pore diameter of $300 \AA$ and particle diameter of $5 \mu \mathrm{m}$ ) with a silica precolumn packed with LiChrosorb Si-60, 7.9$12.4 \mu \mathrm{m}$ (Merck, Darmstadt, Germany) located between the pump and the injector. All Vydac columns were purchased from Grace Vydac (Hesperia, CA, USA). The mobile phase consisted of $71 \%$ Tris- $\mathrm{HCl}$ buffer $(50 \mathrm{mM}, \mathrm{pH} 7.5)$ and 29\% n-propanol, as described by Dalmora et al. [19], with a flow-rate of $0.5 \mathrm{~mL} / \mathrm{min}$, a detector wavelength of $220 \mathrm{~nm}$, a column temperature maintained at $45^{\circ} \mathrm{C}$, and a sample volume of $25-500 \mu \mathrm{L}$ [18]. This methodology was used for analytical purposes to examine the effect of $\mathrm{NaBu}$ on hPRL production. 
$(\mathrm{kDa})$

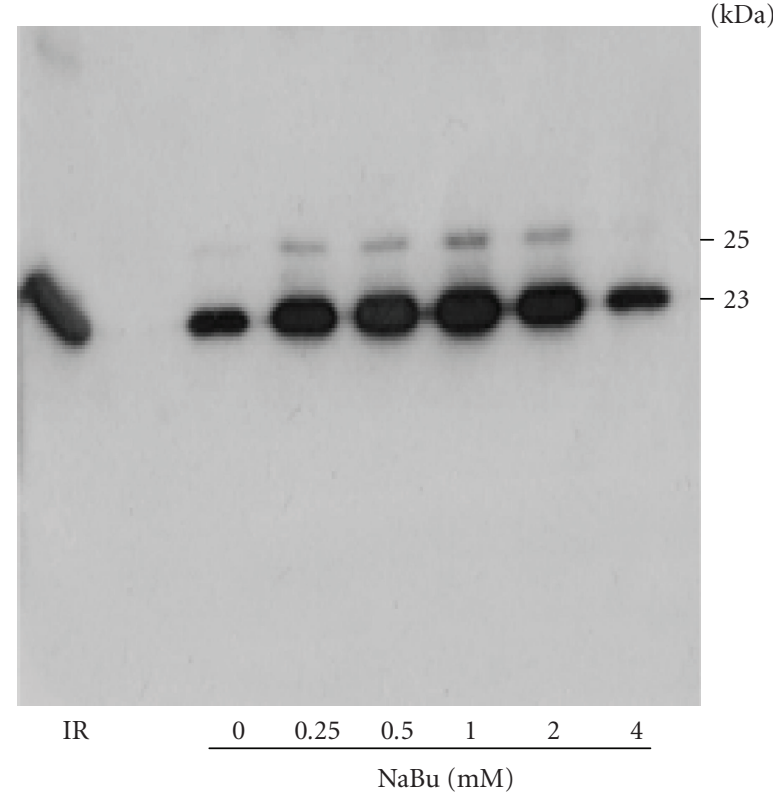

(b)

$(\mathrm{kDa})$

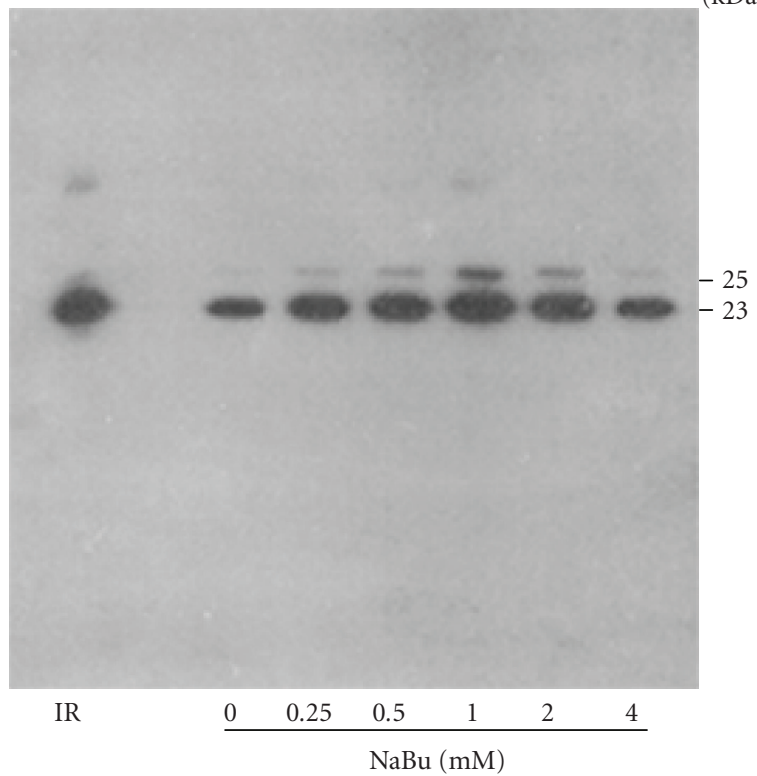

(c)

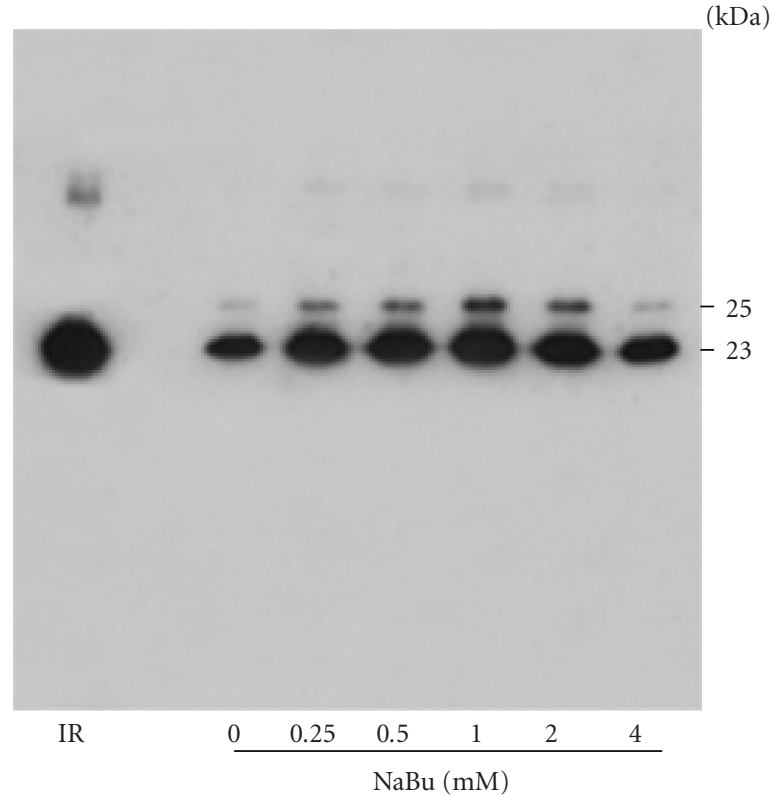

(d)

Figure 4: Western blot analysis of hPRL production in CHO cells treated with different concentrations of NaBu on days 1 (a), 4 (b), 5 (c), and 6 (d). Molecular weights G-hPRL $(25 \mathrm{kDa})$ and NG-hPRL $(23 \mathrm{kDa})$ are indicated. IR: Internal Reference of periplasmic E. coli-derived hPRL.

2.8. High-Performance Size-Exclusion Chromatography (HPSEC). The HPSEC is an entropically controlled separation technique in which molecules are separated on the basis of their hydrodynamic molecular volume or size $[25,26]$. This methodology was used for both analytical and preparative purposes and allowed us to use purified hPRL directly in bioassays, the $n$-propanol interference being absent due to the RP-HPLC technique. HPSEC was carried out with the same Shimadzu apparatus, processing 25 to $500 \mu \mathrm{L}$ of sample on a TosoHaas (Montgomeryville,
PA, USA) G2000 SW column $(60 \mathrm{~cm} \times 7.5 \mathrm{~mm}$ i.d., particle size of $10 \mu \mathrm{m}$ and pore size of $125 \AA$ ) coupled to a $7.5 \mathrm{~cm}$ $\times 7.5 \mathrm{~mm}$ i.d. SW guard column. The mobile phase was $0.025 \mathrm{M}$ ammonium bicarbonate, $\mathrm{pH}$ 7.0, with a flow-rate of $1.0 \mathrm{~mL} / \mathrm{min}$ [19].

2.9. hPRL Purification. The hPRL present in conditioned culture medium was purified as described by Soares et al. [9]. A two-step purification process was used: SP-Sepharose Fast Flow followed by a size exclusion chromatography 


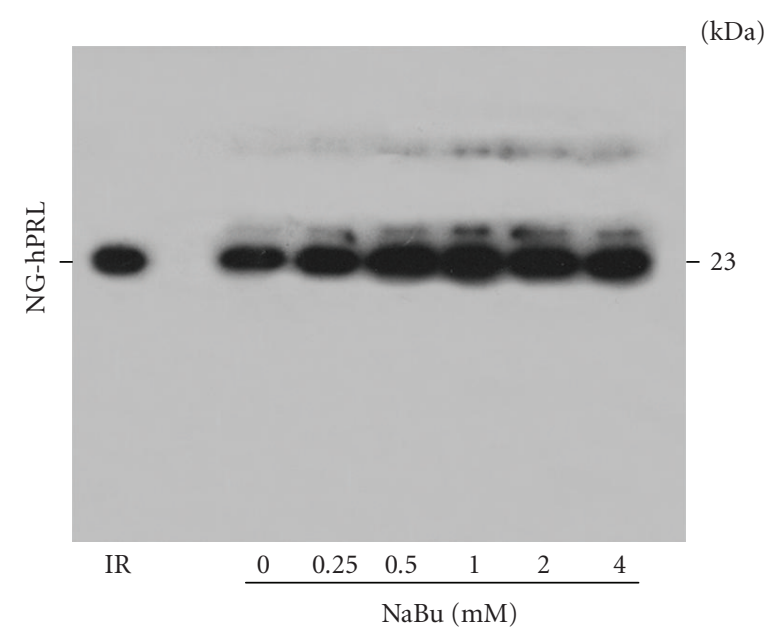

(a)

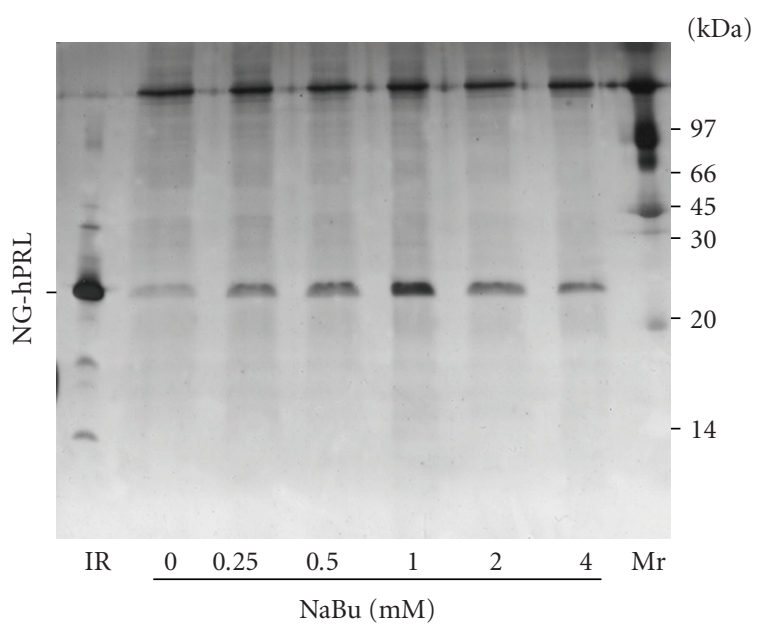

(b)

FIgURE 5: (a) Western blot analysis and (b) SDS-PAGE stained with $\mathrm{AgNO}_{3}$ of 10 -day production pools of hPRL secreted by CHO cells treated with different $\mathrm{NaBu}$ concentrations. IR: Internal Reference of periplasmic E. coli-derived hPRL. Mr: molecular mass marker.

employing HPSEC for preparative purposes. Briefly, conditioned medium $(\sim 500 \mathrm{~mL})$ was adjusted to $\mathrm{pH} 5.0$ using acetic acid. The material was then applied onto the SPSepharose Fast Flow column (GE Healthcare Bio-Science Corp., Piscataway, NJ, USA) equilibrated in $50 \mathrm{mM}$ sodium acetate, $\mathrm{pH}$ 5.0. UV absorbance was monitored at $280 \mathrm{~nm}$. After washing with the same buffer, the column was treated with $50 \mathrm{mM}$ sodium acetate, $\mathrm{pH} 5.0,90 \mathrm{mM} \mathrm{NaCl}$ buffer. The protein of interest was then eluted from the column with $25 \mathrm{mM}$ Hepes, $\mathrm{pH}$ 8.0. Different fractions containing hPRL were analysed by HPSEC and the most concentrated fractions were purified on the same HPSEC column, working this time in a preparative mode. The maximum volume applied in each preparative HPSEC run was $500 \mu \mathrm{L}$. hPRL in the final pool obtained via the HPSEC purification was quantified for bioassay purposes by HPSEC and stored at $-80^{\circ} \mathrm{C}$.

2.10. In Vitro Bioassay. The biological activity of purified hPRL was determined via the Nb2 and Ba/F3-LLP lymphoma cell-proliferation assays, as previously described [27], against the First WHO Reference Reagent of recombinant hPRL, lyophilized in ampoules coded 97/714 [28].

$\mathrm{Ba} / \mathrm{F} 3$-LLP cells were routinely maintained in suspension in RPMI-1640 medium supplemented with $10 \%$ heatinactivated FBS, $2 \mathrm{mM}$ glutamine, $50 \mathrm{U} / \mathrm{mL}$ of penicillin, $50 \mu \mathrm{g} / \mathrm{mL}$ of streptomycin, $700 \mu \mathrm{g} / \mathrm{mL}$ of geneticin and $1 \mathrm{ng} / \mathrm{mL}$ of hPRL. Before carrying out the proliferation assay, cells were starved for 6 hours in the RPMI- 1640 medium, as mentioned above, without hPRL. Cells were then distributed in flat bottom 96-well plates at a density of $5 \times 10^{4}$ cells/well in a final volume of $200 \mu \mathrm{L}$. After 72 hours at $37^{\circ} \mathrm{C}$ and $5 \% \mathrm{CO}_{2}$, the presence of viable cells was assessed using MTS assay [29]. Briefly, $2 \mathrm{mg} / \mathrm{mL}$ MTS dye [3(4,5-dimethylthiazol-2-yl)-5(3-carboxymethoxyphenyl)2-(4-sulf-ophenyl)-2H-tetrazolin (Promega Corp., Madison, WI,USA)] in PBS was mixed in a 20:1 ratio ( $\mathrm{vol} / \mathrm{vol})$ with
TABLE 1: Expression levels and RP-HPLC retention times $\left(t_{R}\right)$ of hPRL obtained from CHO cells treated with different concentrations of $\mathrm{NaBu}$ for 10 days. The $t_{R}$ were compared with those of the Internal Reference Preparation of periplasmic E. coli-derived hPRL $\left(t_{R}: 26.00 \pm 0.72\right.$ minutes $)$.

\begin{tabular}{lll}
\hline $\mathrm{NaBu}(\mathrm{mM})$ & $\begin{array}{l}\text { Expression levels of } \\
\mathrm{hPRL}^{\mathrm{a}}(\mu \mathrm{g} / \mathrm{mL})\end{array}$ & $t_{R}{ }^{\mathrm{a}}(\mathrm{min})$ \\
\hline 0 & $0.92 \pm 0.22$ & $25.81 \pm 0.52$ \\
0.25 & $1.30 \pm 0.06$ & $25.68 \pm 0.47$ \\
0.5 & $1.67 \pm 0.00$ & $25.90 \pm 0.77$ \\
1 & $2.00 \pm 0.03$ & $25.77 \pm 0.73$ \\
2 & $1.48 \pm 0.05$ & $25.66 \pm 0.87$ \\
4 & $1.23 \pm 0.11$ & $25.68 \pm 0.82$ \\
& & Average $t_{R}=25.75 \pm 0.09$ \\
& & RSD $=0.4 \%$ \\
\hline
\end{tabular}

${ }^{\mathrm{a}}$ Each value is the mean $\pm \mathrm{SD}$ of duplicate experiments.

PMS (phenazine methosulphate) (Sigma, St. Louis, MO, USA), $0.92 \mathrm{mg} / \mathrm{mL}$ in PBS. Twenty microliters of mixture were then added to each well, and 2 hours after incubation at $37^{\circ} \mathrm{C}$ the absorbance at $490 \mathrm{~nm}$ was read in a microplate reader (Multiskan EX Thermo Electron Corporation, Vantaa, Finland).

$\mathrm{Nb} 2$ cells also routinely maintained in suspension in RPMI-1640 medium supplemented with $10 \%$ heatinactivated FBS, $2 \mathrm{mM}$ glutamine, $50 \mathrm{U} / \mathrm{mL}$ of penicillin, and $50 \mu \mathrm{g} / \mathrm{mL}$ of streptomycin mixed in a $50: 1 \mathrm{ratio}(\mathrm{vol} / \mathrm{vol}$ ) with $5 \mathrm{mM} 2-\beta$ mercaptoethanol in PBS. Before carrying out the proliferation assay, cells were maintained in the RPMI1640 , as mentioned above, containing $1 \%$ heat-inactivated FBS for 8 hours, constituting the preassay. Afterward, the cells were distributed in flat bottom 96 -well plates at a density of $2 \times 10^{4}$ cells/well in a final volume of $200 \mu \mathrm{L}$, with no heat-inactivated FBS addition. After 72 hours at $37^{\circ} \mathrm{C}$ and 


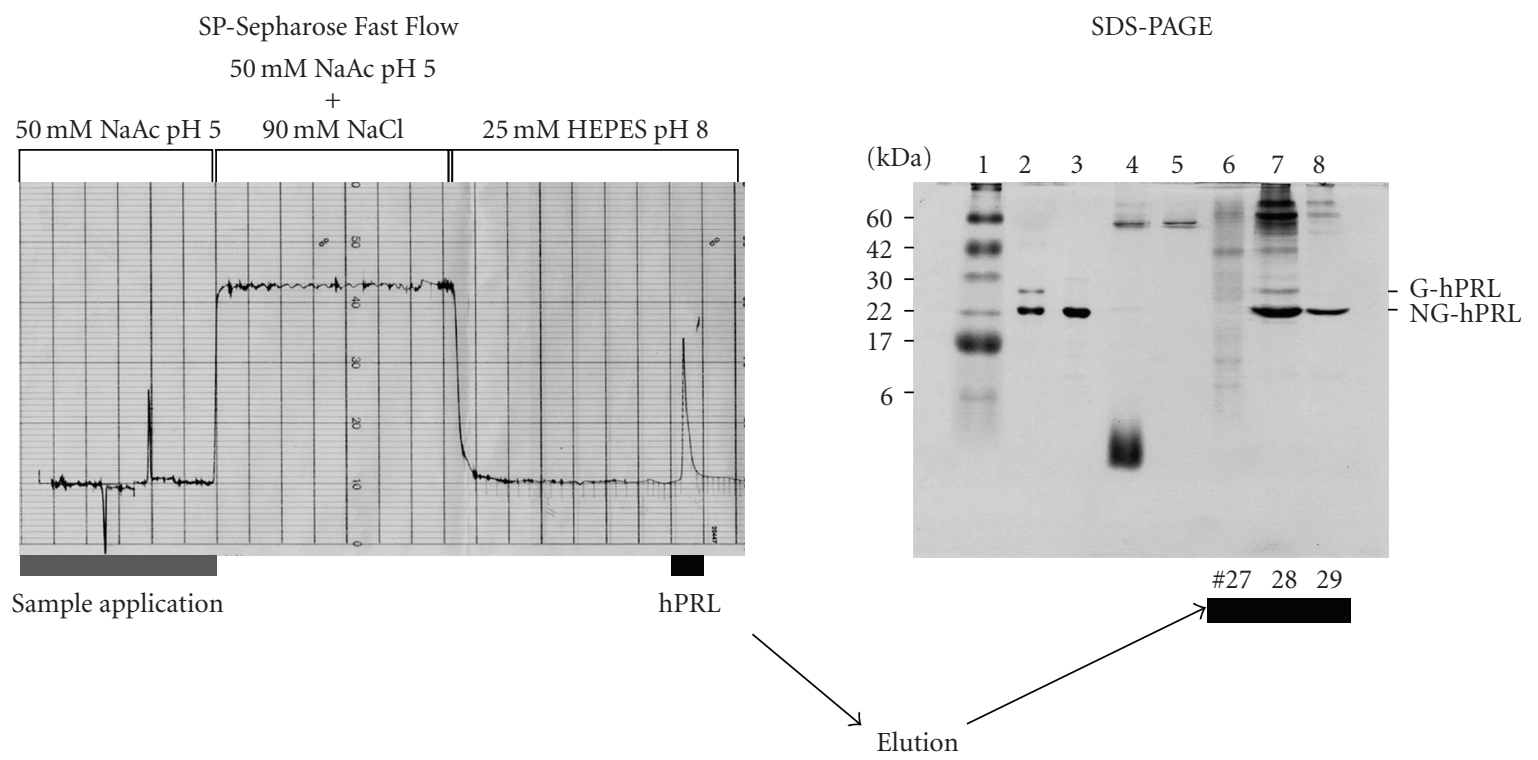

(a)

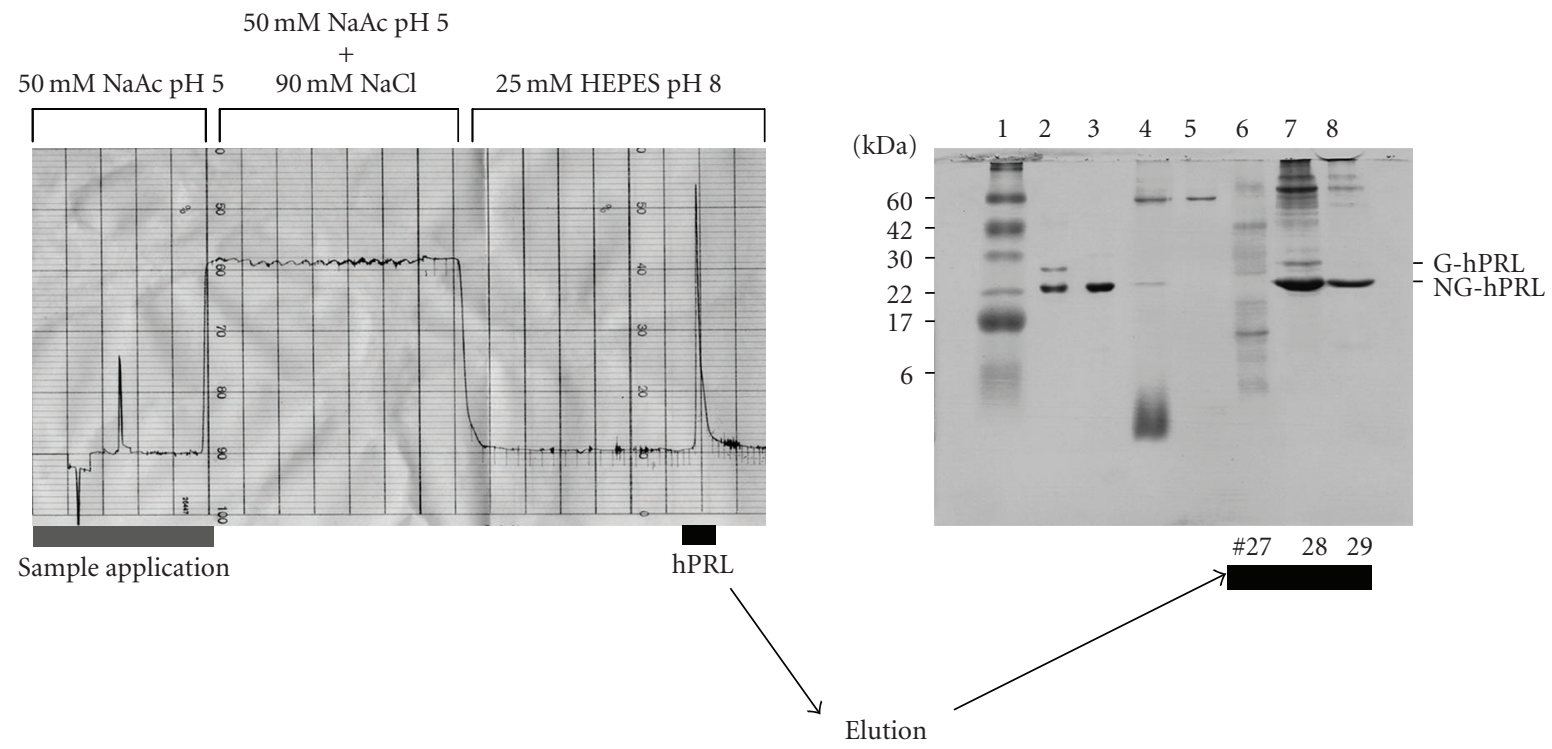

(b)

FIGURE 6: Example of chromatographic purification of hPRL on SP-Sepharose Fast Flow and SDS-PAGE analysis of CHO cell-conditioned medium of (a) nontreated cells and (b) cells treated with $1 \mathrm{mM} \mathrm{NaBu}$. Lane 1: molecular mass marker. Lane 2: Chemical Reference Standard of G-hPRL and NG-hPRL (WHO-CRS). Lane 3: Internal Reference of periplasmic E. coli-derived hPRL. Lane 4: CHO-conditioned medium. Lane 5: unretained fraction. Lanes 6-8: fractions eluted with 25 mM HEPES, pH 8.0. NaAc: sodium acetate.

$5 \% \mathrm{CO}_{2}$, the presence of viable cells was assessed using MTS assay, as mentioned before.

\section{Results}

3.1. Cell Growth and Viability. The influence of different concentrations of $\mathrm{NaBu}$ on hPRL-secreting $\mathrm{CHO}$ cellular growth and viability during a 10-day culture can be seen in Figure 1. The treatment with either 0.25 or $0.5 \mathrm{mM}$
$\mathrm{NaBu}$ did not result in significant growth inhibition $(P>$ 0.05) compared to the control without $\mathrm{NaBu}$ (Figure 1(a)). Nonetheless, a dose response-effect on cellular growth was observed in the concentration range of 1 to $4 \mathrm{mM} \mathrm{NaBu}$, with a dramatic fall already occurring after day 2 at the concentrations of $2 \mathrm{mM}$ and $4 \mathrm{mM} \mathrm{NaBu}$. The treatment with $1 \mathrm{mM} \mathrm{NaBu}$ produced an apparent decline only 4 days after starting the treatment. With regard to cell viability, none of the concentrations except $4 \mathrm{mM} \mathrm{NaBu}(P<0.05)$ showed any significant effect (Figure 1(b)). 


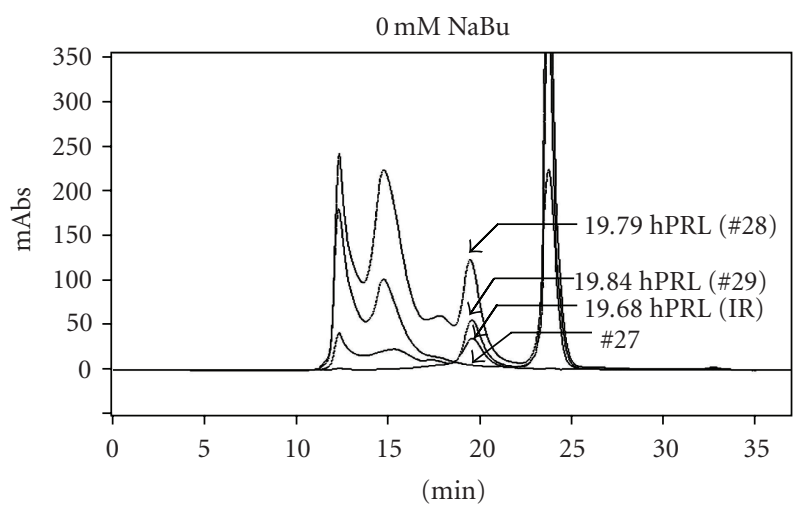

(a)

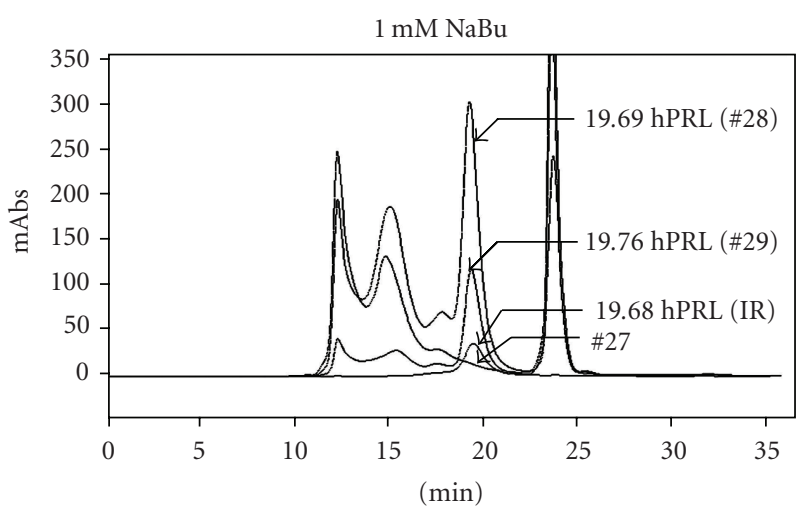

(b)

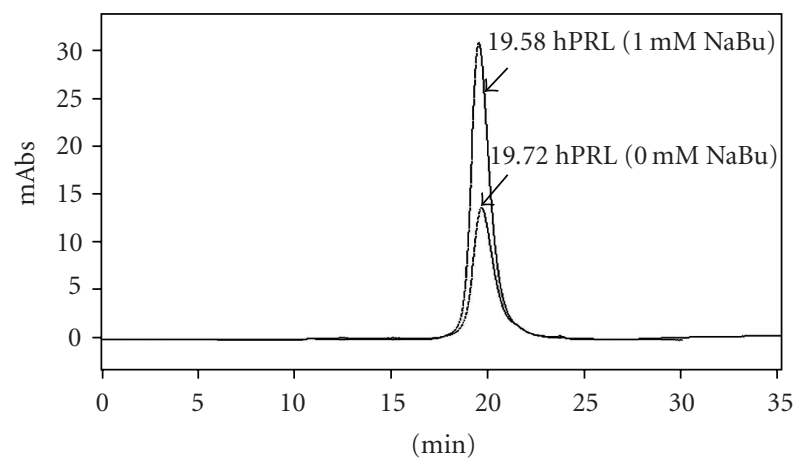

(c)

FIGURE 7: (a) and (b) Qualitative and quantitative HPSEC analysis of NaBu-treated and untreated CHO-derived hPRL after SP-Sepharose Fast Flow and (c) after preparative HPSEC purification, comparing the product obtained from tube \#28 of nontreated (a) and NaBu-treated cells (b). IR: Internal Reference of periplasmic E. coli-derived hPRL (7.0 $\mu \mathrm{g})$. mAbs: milliabsorbance. Tube numbers (\#27, \#28, and \#29) are from SP-Sepharose chromatography. Retention Times $\left(t_{R}\right)$ are indicated.

The rate of apoptosis in $\mathrm{NaBu}$-treated and untreated $\mathrm{CHO}$ cells was examined by polyacrylamide gel electrophoresis and revealed by silver staining. Figure 2 shows that $\mathrm{NaBu}-$ treated and untreated $\mathrm{CHO}$ cells exhibit oligonucleosomal DNA ladder which is the hallmark of apoptosis, resulting from endonuclease activity at internucleosomal sites in an apoptotic cell. The intensity of the oligonucleosomal DNA ladder seems $\mathrm{NaBu}$ dose-dependent. On the other hand, the progressive removal of dFBS from the culture medium could also be associated with apoptotic cell death in $\mathrm{NaBu}-$ treated and untreated $\mathrm{CHO}$ cells, leading to a decrease of cellular growth after day 5 . This can be due to the fact that serum contains growth factors that help the culture survival [30].

3.2. Effect of NaBu on hPRL Production. A RP-HPLC methodology, previously set up in our laboratory specifically for hPRL qualitative and quantitative analysis [18], was then employed to quantify hPRL production and detect the presence of possible alteration in hPRL structure or hydrophobicity due to the prolonged presence of $\mathrm{NaBu}$. The data in Table 1 and Figure 3 show that $1 \mathrm{mM} \mathrm{NaBu}$ is capable of greatly increasing hPRL synthesis $(P<0.02)$, with no significant differences $(P>0.05)$ in the retention time $\left(t_{R}\right)$ of the resultant hPRL up to $4 \mathrm{mM} \mathrm{NaBu}$.
Human prolactin quantification carried out by RP-HPLC in $\mathrm{CHO}$ cell-conditioned medium (Table 1) indicated that the highest production was obtained with $1 \mathrm{mM} \mathrm{NaBu}$, which increased the secretion $\sim 2$-fold relative to control cultivation without $\mathrm{NaBu}$ addition. Despite an increase in protein expression, the concentrations of $0.5 \mathrm{mM}$ and $2 \mathrm{mM}$ $\mathrm{NaBu}$ provided lower hPRL volumetric yields than $1 \mathrm{mM}$ $\mathrm{NaBu}$. The greatest inhibition of cell growth was produced by $4 \mathrm{mM} \mathrm{NaBu}$ leading to lower hPRL synthesis (Figure 1 (a) and Table 1). Clearly, it will be important to determine the optimal $\mathrm{NaBu}$ concentration in long-term cell cultures.

To confirm the expression and purity level of hPRL, equal volumes of $\mathrm{CHO}$-conditioned medium, collected on days $1,4,5$, and 6 , were analyzed by Western blot (Figure 4); the same was done with pools obtained after 10 days of cultivation (Figure 5(a)). These pools were also analyzed via SDS-PAGE followed by $\mathrm{AgNO}_{3}$ staining (Figure 5(b)), which demonstrated the predominance, with $1 \mathrm{mM} \mathrm{NaBu}$, of hPRL relative to other proteins that might be present in $\mathrm{CHO}$ cell-conditioned medium. Taken together, these RP-HPLC, Western blot, and SDS-PAGE analyses indicate that, under our conditions, $1 \mathrm{mM} \mathrm{NaBu}$ was the ideal concentration, providing the highest hPRL expression level, while still maintaining good cell viability and only a limited decrease in cell growth. 
TABLE 2: Recombinant hPRL purification starting from $500 \mathrm{~mL}$ of $\mathrm{NaBu}$-treated or untreated $\mathrm{CHO}$-conditioned medium.

\begin{tabular}{lcccccc}
\hline \multirow{2}{*}{ Purification step } & \multicolumn{2}{c}{ Total protein $(\mathrm{mg})^{\mathrm{a}}$} & \multicolumn{2}{c}{ hPRL $(\mathrm{mg})$} & \multicolumn{2}{c}{ Mass fraction } \\
& $0 \mathrm{mM} \mathrm{NaBu}$ & $1 \mathrm{mM} \mathrm{NaBu}$ & $0 \mathrm{mM} \mathrm{NaBu}$ & $1 \mathrm{mM} \mathrm{NaBu}$ & $0 \mathrm{mM} \mathrm{NaBu}$ & $1 \mathrm{mM} \mathrm{NaBu}$ \\
\hline Conditioned medium & 64.7 & 66.2 & 0.54 & $1.20^{\mathrm{b}}$ & 0.008 & 0.018 \\
SP-Sepharose FF & 2.3 & 3.0 & 0.51 & $1.22^{\mathrm{c}}$ & 0.219 & 0.403 \\
Preparative HPSEC & 0.14 & 0.25 & 0.13 & $0.25^{\mathrm{c}}$ & 0.978 & 1.000 \\
\hline
\end{tabular}

${ }^{a}$ Estimated by BCA assay. ${ }^{b}$ Estimated by RP-HPLC. ${ }^{c}$ Estimated by HPSEC.

TABLE 3: Bioactivity of purified hPRL obtained from CHO cells treated or not with $\mathrm{NaBu}$, determined via $\mathrm{Nb} 2$ or $\mathrm{Ba} / \mathrm{F} 3$-LLP cells against the First International Standard for recombinant hPRL (WHO 97/714) with an activity of $57.2 \pm 11.4 \mathrm{IU} / \mathrm{mg}$.

\begin{tabular}{lll}
\hline & IU/mg hPRL & \\
Cells & $0 \mathrm{mM} \mathrm{NaBu}$ & $1 \mathrm{mM} \mathrm{NaBu}$ \\
\hline $\mathrm{Nb} 2$ & $50.88 \pm 5.33$ & $61.21 \pm 4.66$ \\
$\mathrm{Ba} / \mathrm{F} 3-\mathrm{LLP}$ & $50.07 \pm 5.64$ & $71.47 \pm 4.33$ \\
\hline
\end{tabular}

${ }^{a}$ Values are means \pm SD of two independent assays, each run with intraassay quadruplicates.

SP-Sepharose Fast Flow chromatographic purification of $\mathrm{NaBu}$-treated and untreated cells, together with SDS-PAGE analysis of applied and eluted fractions, is shown in Figure 6. This confirmed the presence of about twice as much hPRL in the medium treated with $1 \mathrm{mM} \mathrm{NaBu}$ and the efficient adsorption of both the $25 \mathrm{kDa}$ glycosylated (G-hPRL) and the $23 \mathrm{kDa}$ nonglycosylated hPRL (NG-hPRL) isoforms by the cationic exchanger [31].

The same partially purified products were also analyzed by HPSEC before and after using this same column for preparative purposes (Figures $7(\mathrm{a}), 7(\mathrm{~b})$, and $7(\mathrm{c})$ ). The purity obtained for both products after this second chromatographic step is noteworthy (>97\%) (Figure 7(c) and Table 2). From Table 2, on the basis of mass fractions, it is possible to calculate an overall purification factor of $\sim 55$ and 122-fold for $\mathrm{NaBu}$-treated and untreated $\mathrm{CHO}$ cells, respectively. The $\sim 2$-fold increase in hPRL production obtained in the presence of $1 \mathrm{mM} \mathrm{NaBu}$ was also confirmed after purification. Also remarkable are the perfectly coincident $t_{R}$ values of the two $\mathrm{CHO}$-derived hPRL preparations and of the Internal Reference of $E$. coli-derived hPRL (19.58 minutes $<t_{R}<19.72$ minutes), confirming their identical hydrodynamic properties in this long $(60 \mathrm{~cm})$ HPSEC column (Figure $7(\mathrm{c})$ ). It has been reported that these properties can be altered even by subtle modifications in the secondary and tertiary structure of the molecule $[32,33]$.

3.3. Biological Assays. Finally, the two purified products were tested for their biological activity against the Reference Reagent for recombinant hPRL (WHO 97/714) in two different in vitro bioassays based on $\mathrm{Nb} 2$ and Ba/F3-LLP cells. The data illustrated in Figure 8 and reported in Table 3 show that apparently there were no differences between the potencies of the purified products and that of the WHO Reference Reagent.

\section{Discussion}

Previous studies have examined the production of recombinant proteins by $\mathrm{NaBu}$-treated $\mathrm{CHO}$ cells. Several of these have discussed the benefits or warned against the problems caused by the presence of $\mathrm{NaBu}$ [14-16]. $\mathrm{NaBu}$ has, in fact, been used for increasing the expression of foreign proteins in animal cell cultures. It is recognized that $\mathrm{NaBu}$ alters primarily chromatin structure through inhibition of histone deacetylases, resulting in hyperacetylation of histones and, consequently, alterations in DNA transcription. Therefore, these alterations might be correlated with the modulation of gene expression [11]. On the other hand, hyperacetylation of histones in $\mathrm{NaBu}$-treated mammalian cancer cell lines has been shown to induce apoptosis mediated by activation of caspase- 3 activity, leading to the translation of putative cell death proteins [34] and resulting in an increased possibility of DNA cleavage [35].

In this study, we examined the expression level and quality of hPRL directly in CHO cell-conditioned medium, after adding different amounts of $\mathrm{NaBu}$. The different $\mathrm{NaBu}$ concentrations $(0.25$ to $2 \mathrm{mM})$ remarkably increased hPRL expression.

Addition of $1 \mathrm{mM} \mathrm{NaBu}$ to the culture medium resulted in a twofold increase in hPRL expression, with only a relatively small decrease in cell growth compared with the untreated control; this was confirmed by RP-HPLC and by Western blot and SDS-PAGE analysis. Although $2 \mathrm{mM}$ and $4 \mathrm{mM} \mathrm{NaBu}$ apparently induced a higher synthesis of hPRL in the first 24 hours of treatment, this synthesis exhibited a decrease in the following days of culture. A higher $\mathrm{NaBu}$ concentration ( 2 or $4 \mathrm{mM}$ ) may be more effective in inhibiting the activity of histone deacetylases and, consequently, increase the initial expression of proteins. However, a greater modification of the chromatin structure could make the DNA more susceptible to apoptotic action of endonucleases, leading to decreased productivity of hPRL.

The addition of different $\mathrm{NaBu}$ concentrations apparently did not affect the hydrophobicity or the hydrodynamic proprieties of the hPRL molecule. This was inferred from the fact that the $t_{R}$ values determined by RP-HPLC and HPSEC were not significantly altered by the $\mathrm{NaBu}$ treatment relative to the untreated control or the internal reference standard of periplasmic E. coli-derived hPRL. Our analytical determinations, as a difference from other authors that studied $\mathrm{NaBu}$ influence on heterologous protein production with basis on immunological techniques [15-17], have been mostly based on physicochemical methodologies. 


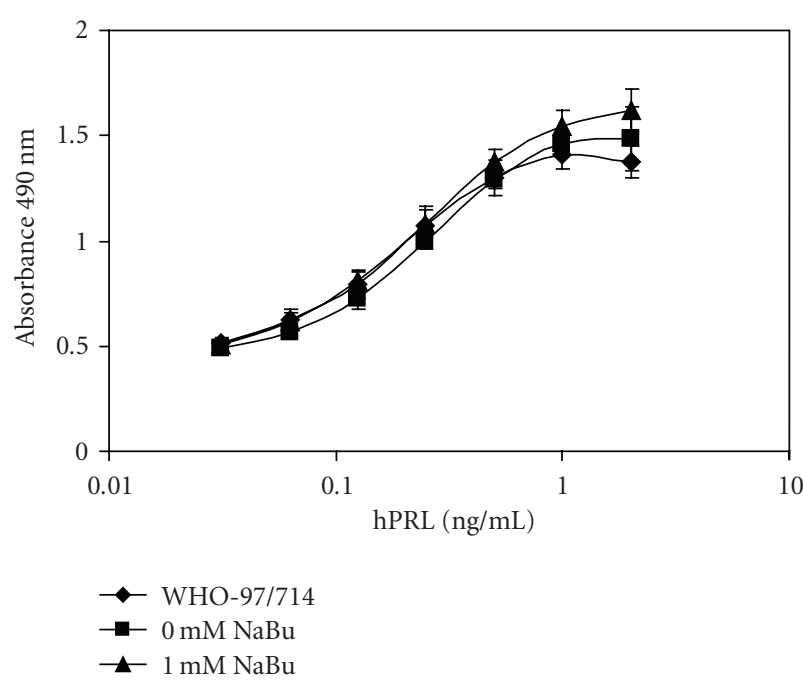

(a)

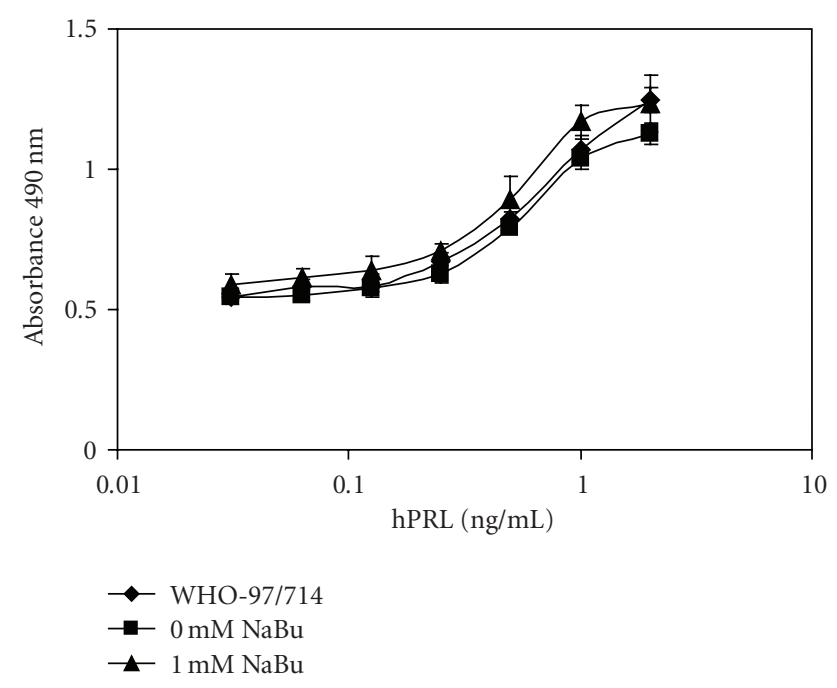

(b)

FIGURE 8: Bioactivity of purified hPRL obtained from CHO cells treated or not with NaBu, determined via (a) Nb2 or (b) Ba/F3-LLP cell assays against the International Standard of Recombinant hPRL (WHO 97/714). Values are the mean of two independent determinations.

The cell viability for different concentrations of $\mathrm{NaBu}$ was similar to that of the untreated control except in the experiments with $4 \mathrm{mM}$ added $\mathrm{NaBu}$. Therefore, the arrest of cell growth after day 5 and similar decrease in cell viability between $0-2 \mathrm{mM} \mathrm{NaBu}$ was probably caused by removal of dFBS from the culture medium and $\mathrm{NaBu}$ treatment during the production process. This could make the $\mathrm{CHO}$ cell more susceptible to apoptosis, leading to decreased cellular density and viability.

Finally, two different in vitro bioassays for purified hPRL, based on $\mathrm{Nb} 2$ and $\mathrm{Ba} / \mathrm{F} 3$-LLP cells, were carried out. The first bioassay is the classical heterologous $\mathrm{Nb} 2$ rat lymphoma cell proliferation assay [36], while the second is the recently developed homologous $\mathrm{Ba} / \mathrm{F} 3$-LLP assay [37], based on murine pro- $\mathrm{B}$ lymphoma cells containing the sequence encoding the human PRL receptor and previously utilized in our laboratory $[9,27]$. As described by Crowell et al. [38], $\mathrm{NaBu}$ treatment can potentially modify the oligosaccharide content of glycoproteins in various expression systems. Although $\mathrm{NaBu}$ apparently has no effect on the protein structure of hPRL, there might be modifications of the oligosaccharide structure of G-hPRL. In this regard, it is known that the oligosaccharide nature and content can influence the in vivo bioactivities of a glycoprotein [3942]. It is therefore important to note that the potency of hPRL obtained in the presence of $\mathrm{NaBu}$ was comparable to that of the Reference Reagent for recombinant hPRL (WHO 97/714). In conclusion, for the first time recombinant hPRL production from genetically modified $\mathrm{CHO}$ cells has been significant increased ( $\sim 2$-fold) via $\mathrm{NaBu}$ addition, apparently without compromising either its structure or function; the quantitative and qualitative effects of this addition have been determined via accurate physicochemical techniques. The same treatment can potentially be applied to other hormones, for example, human thyrotropin (hTSH), which is also produced in our laboratory [43]. The qualitative and quantitative influence of this treatment on the carbohydrate moieties of G-hPRL and possibly of other glycohormones requires further investigation.

\section{Acknowledgments}

The authors are grateful to José Maria de Sousa and João Ezequiel de Oliveira for valuable and skilled technical assistance. This work was supported by Fundação de Amparo à Pesquisa do Estado de São Paulo (FAPESP), São Paulo, Brazil (Projects 05/60826-3, 06/52973-9, 07/59709-8, 07/59540-3, 07/54493-7), by Conselho Nacional de Pesquisa (CNPq), Brasília, Brazil (Project PQ300473/2009-2), and by FK Biotecnologia/Proteogenética (Porto Alegre, RS, Brazil).

\section{References}

[1] M. C. Tettamanzi, C. Keeler, S. Meshack, and M. E. Hodsdon, "Analysis of site-specific histidine protonation in human prolactin," Biochemistry, vol. 47, no. 33, pp. 8638-8647, 2008.

[2] M. E. Freeman, B. Kanyicska, A. Lerant, and G. Nagy, "Prolactin: structure, function, and regulation of secretion," Physiological Reviews, vol. 80, no. 4, pp. 1523-1631, 2000.

[3] G. Goodman and D. Bercovich, "Prolactin does not cause breast cancer and may prevent it or be therapeutic in some conditions," Medical Hypotheses, vol. 70, no. 2, pp. 244-251, 2008.

[4] N. Ben-Jonathan, J. L. Mershon, D. L. Allen, and R. W. Steinmetz, "Extrapituitary prolactin: distribution, regulation, functions, and clinical aspects," Endocrine Reviews, vol. 17, no. 6, pp. 639-669, 1996.

[5] N. Ben-Jonathan, K. Liby, M. McFarland, and M. Zinger, "Prolactin as an autocrine/paracrine growth factor in human cancer," Trends in Endocrinology and Metabolism, vol. 13, no. 6, pp. 245-250, 2002. 
[6] L. Morganti, M. Huyer, P. W. Gout, and P. Bartolini, "Production and characterization of biologically active Ala-Ser(His)6-lle-Glu-Gly-Arg-human prolactin (tag-hPRL) secreted in the periplasmic space of Escherichia coli," Biotechnology and Applied Biochemistry, vol. 23, no. 1, pp. 67-75, 1996.

[7] L. Morganti, C. R. J. Scares, R. Affonso, P. W. Gout, and P. Bartolini, "Synthesis and characterization of recombinant, authentic human prolactin secreted into the periplasmic space of Escherichia coli," Biotechnology and Applied Biochemistry, vol. 27, part 1, pp. 63-70, 1998.

[8] C. R. J. Soares, L. Morganti, B. Miloux, J. H. Lupker, P. Ferrara, and P. Bartolini, "High-level synthesis of human prolactin in Chinese-hamster ovary cells," Biotechnology and Applied Biochemistry, vol. 32, no. 2, pp. 127-135, 2000.

[9] C. R. J. Soares, A. Glezer, K. Okazaki, et al., "Physico-chemical and biological characterizations of two human prolactin analogs exhibiting controversial bioactivity, synthesized in Chinese hamster ovary (CHO) cells," Protein Expression and Purification, vol. 48, no. 2, pp. 182-194, 2006.

[10] C. R. J. Soares, E. K. M. Ueda, T. L. Oliveira, F. I. C. Gomide, S. R. Heller, and P. Bartolini, "Distinct human prolactin (hPRL) and growth hormone (hGH) behavior under bacteriophage lambda P promoter control: temperature plays a major role in protein yields," Journal of Biotechnology, vol. 133, no. 1, pp. 27-35, 2008.

[11] J. R. Davie, "Inhibition of histone deacetylase activity by butyrate," Journal of Nutrition, vol. 133, no. 7, supplement, pp. 2485S-2493S, 2003.

[12] M.-P. Leibovitch, S.-A. Leibovitch, J. Harel, and J. Kruh, "Effect of sodium butyrate on messenger RNA populations in myogenic cells in culture," Differentiation, vol. 22, no. 2, pp. 106-112, 1982.

[13] D. Y. Lee, J. J. Hayes, D. Pruss, and A. P. Wolffe, "A positive role for histone acetylation in transcription factor access to nucleosomal DNA,” Cell, vol. 72, no. 1, pp. 73-84, 1993.

[14] N. S. Kim and G. M. Lee, "Overexpression of bcl-2 inhibits sodium butyrate-induced apoptosis in Chinese hamster ovary cells resulting in enhanced humanized antibody production," Biotechnology and Bioengineering, vol. 71, no. 3, pp. 184-193, 2000.

[15] Y. Mimura, J. Lund, S. Church, et al., "Butyrate increases production of human chimeric IgG in CHO-K1 cells whilst maintaining function and glycoform profile," Journal of Immunological Methods, vol. 247, no. 1-2, pp. 205-216, 2001.

[16] K. O. Han, K. S. Moon, J. Yang, et al., "Effect of NAcetylcystein on butyrate-treated Chinese hamster ovary cells to improve the production of recombinant human interferonbeta-1a," Biotechnology Progress, vol. 21, no. 4, pp. 1154-1164, 2005.

[17] H. S. Yun and M. L. Gyun, "Enhanced human thrombopoietin production by sodium butyrate addition to serumfree suspension culture of Bcl-2-overexpressing CHO cells," Biotechnology Progress, vol. 21, no. 1, pp. 50-57, 2005.

[18] C. R. J. Soares, I. M. C. Camargo, L. Morganti, et al., "Reversed-phase high-performance liquid chromatography method for the determination of prolactin in bacterial extracts and in its purified form," Journal of Chromatography A, vol. 955, no. 2, pp. 229-236, 2002.

[19] S. Dalmora, J. E. Oliveira, R. Affonso, E. Gimbo, M. T. C. P. Ribela, and P. Bartolini, "Analysis of recombinant human growth hormone directly in osmotic shock fluids," Journal of Chromatography A, vol. 782, no. 2, pp. 199-210, 1997.
[20] J. R. Tennant, "Evaluation of the trypan blue technique for determination of cell viability," Transplantation, vol. 2, pp. 685-694, 1964.

[21] B. J. Bassam, G. Caetano-Anolles, and P. M. Gresshoff, "Fast and sensitive silver staining of DNA in polyacrylamide gels," Analytical Biochemistry, vol. 196, no. 1, pp. 80-83, 1991.

[22] U. K. Laemmli, "Cleavage of structural proteins during the assembly of the head of bacteriophage T4," Nature, vol. 227, no. 5259 , pp. 680-685, 1970.

[23] D. D. Bannerman, J. C. Tupper, R. D. Erwert, R. K. Winn, and J. M. Harlan, "Divergence of bacterial lipopolysaccharide pro-apoptotic signaling downstream of IRAK-1," Journal of Biological Chemistry, vol. 277, no. 10, pp. 8048-8053, 2002.

[24] M. T. C. P. Ribela, A. C. Bianco, and P. Bartolini, "The use of recombinant human thyrotropin produced by Chinese hamster ovary cells for the preparation of immunoassay reagents," Journal of Clinical Endocrinology and Metabolism, vol. 81, no. 1, pp. 249-256, 1996.

[25] M. T. C. P. Ribela, P. W. Gout, J. E. Oliveira, and P. Bartolini, "HPLC analysis of human pituitary hormones for pharmaceutical applications," Current Pharmaceutical Analysis, vol. 2, no. 2, pp. 103-126, 2006.

[26] G. W. White, T. Katona, and J. P. Zodda, "The use of highperformance size exclusion chromatography (HPSEC) as a molecular weight screening technique for polygalacturonic acid for use in pharmaceutical applications," Journal of Pharmaceutical and Biomedical Analysis, vol. 20, no. 6, pp. 905-912, 1999.

[27] A. Glezer, C. R. J. Soares, J. G. Vieira, et al., "Human macroprolactin displays low biological activity via its homologous receptor in a new sensitive bioassay," Journal of Clinical Endocrinology and Metabolism, vol. 91, no. 3, pp. 1048-1055, 2006.

[28] B. Rafferty, P. Rigsby, R. E. Gaines-Das, et al., "Draft report of an international collaborative study of proposed WHO reference reagents for rDNA-derived prolactin and its glycosylated and non-glycosylated componentes," WHO Technical Report Series, vol. 52, no. 924, 2001.

[29] T.-J. Chen, C. B. Kuo, K. F. Tsai, J. O.-W. Liu, D.-Y. Chen, and A. M. Walker, "Development of recombinant human prolactin receptor antagonists by molecular mimicry of the phosphorylated hormone," Endocrinology, vol. 139, no. 2, pp. 609-616, 1998.

[30] Y.-S. Lee, H. Nakajima, Y.-C. Chang, et al., "Alleviation of apoptosis by serum in Chinese hamster ovary cells ectopically expressing human Fas antigen," Molecules and Cells, vol. 8, no. 3, pp. 272-279, 1998.

[31] S. R. Heller, H. Rodrigues Goulart, F. S. Arthuso, T. L. Oliveira, P. Bartolini, and C. R. J. Soares, "Synthesis, purification and characterization of recombinant glycosylated human prolactin (G-hPRL) secreted by cycloheximide-treated CHO cells," Journal of Biotechnology, vol. 145, no. 4, pp. 334-340, 2010.

[32] M. T. C. P. Ribella and P. Bartolini, "Stokes radius determination of radioiodinated polypeptide hormones by gel filtration," Analytical Biochemistry, vol. 174, no. 2, pp. 693$697,1988$.

[33] C. M. Carvalho, J. E. Oliveira, B. E. Almeida, et al., "Efficient isolation of the subunits of recombinant and pituitary glycoprotein hormones," Journal of Chromatography A, vol. 1216, no. 9, pp. 1431-1438, 2009.

[34] V. Medina, B. Edmonds, G. P. Young, R. James, S. Appleton, and P. D. Zalewski, "Induction of caspase-3 protease activity and apoptosis by butyrate and trichostatin a (inhibitors of histone deacetylase): dependence on protein synthesis 
and synergy with a mitochondrial/cytochrome c-dependent pathway," Cancer Research, vol. 57, no. 17, pp. 3697-3707, 1997.

[35] P. J. Smith, "n-Butyrate alters chromatin accessibility to DNA repair enzymes," Carcinogenesis, vol. 7, no. 3, pp. 423-429, 1986.

[36] T. Tanaka, R. P. C. Shiu, and P. W. Gout, "A new sensitive and specific bioassay for lactogenic hormones: measurement of prolactin and growth hormone in human serum," Journal of Clinical Endocrinology \& Metabolism, vol. 51, no. 5, pp. 10581063, 1980.

[37] S. Bernichtein, S. Jeay, R. Vaudry, P. A. Kelly, and V. Goffin, "New homologous bioassays for human lactogens show that agonism or antagonism of various analogs is a function of assay sensitivity," Endocrine, vol. 20, no. 1-2, pp. 177-190, 2003.

[38] C. K. Crowell, Q. Qin, G. E. Grampp, R. A. Radcliffe, G. N. Rogers, and R. I. Scheinman, "Sodium butyrate alters erythropoietin glycosylation via multiple mechanisms," Biotechnology and Bioengineering, vol. 99, no. 1, pp. 201-213, 2008.

[39] R. Damiani, J. E. Oliveira, K. Vorauer-Uhl, et al., "Stable expression of a human-like sialylated recombinant thyrotropin in a Chinese hamster ovary cell line expressing alpha2,6-sialyltransferase," Protein Expression and Purification, vol. 67, no. 1, pp. 7-14, 2009.

[40] C. F. Goochee, M. J. Gramer, D. C. Andersen, J. B. Bahr, and J. R. Rasmussen, "The oligosaccharides of glycoproteins: bioprocess factors affecting oligosaccharide structure and their effect on glycoprotein properties," Biotechnology, vol. 9, no. 12, pp. 1347-1355, 1991.

[41] F. Mendonça, J. E. Oliveira, P. Bartolini, and M. T. C. P. Ribela, "Two-step chromatographic purification of recombinant human thyrotrophin and its immunological, biological, physico-chemical and mass spectral characterization," Journal of Chromatography A, vol. 1062, no. 1, pp. 103-112, 2005.

[42] M. W. Szkudlinski, V. Fremont, C. Ronin, and B. D. Weintraub, "Thyroid-stimulating hormone and thyroidstimulating hormone receptor structure-function relationships," Physiological Reviews, vol. 82, no. 2, pp. 473-502, 2002.

[43] C. N. Peroni, C. R. J. Soares, E. Gimbo, L. Morganti, M. T. C. P. Ribela, and P. Bartolini, "High-level expression of human thyroid-stimulating hormone in Chinese hamster ovary cells by co-transfection of dicistronic expression vectors followed by a dual-marker amplification strategy," Biotechnology and Applied Biochemistry, vol. 35, part 1, pp. 19-26, 2002. 

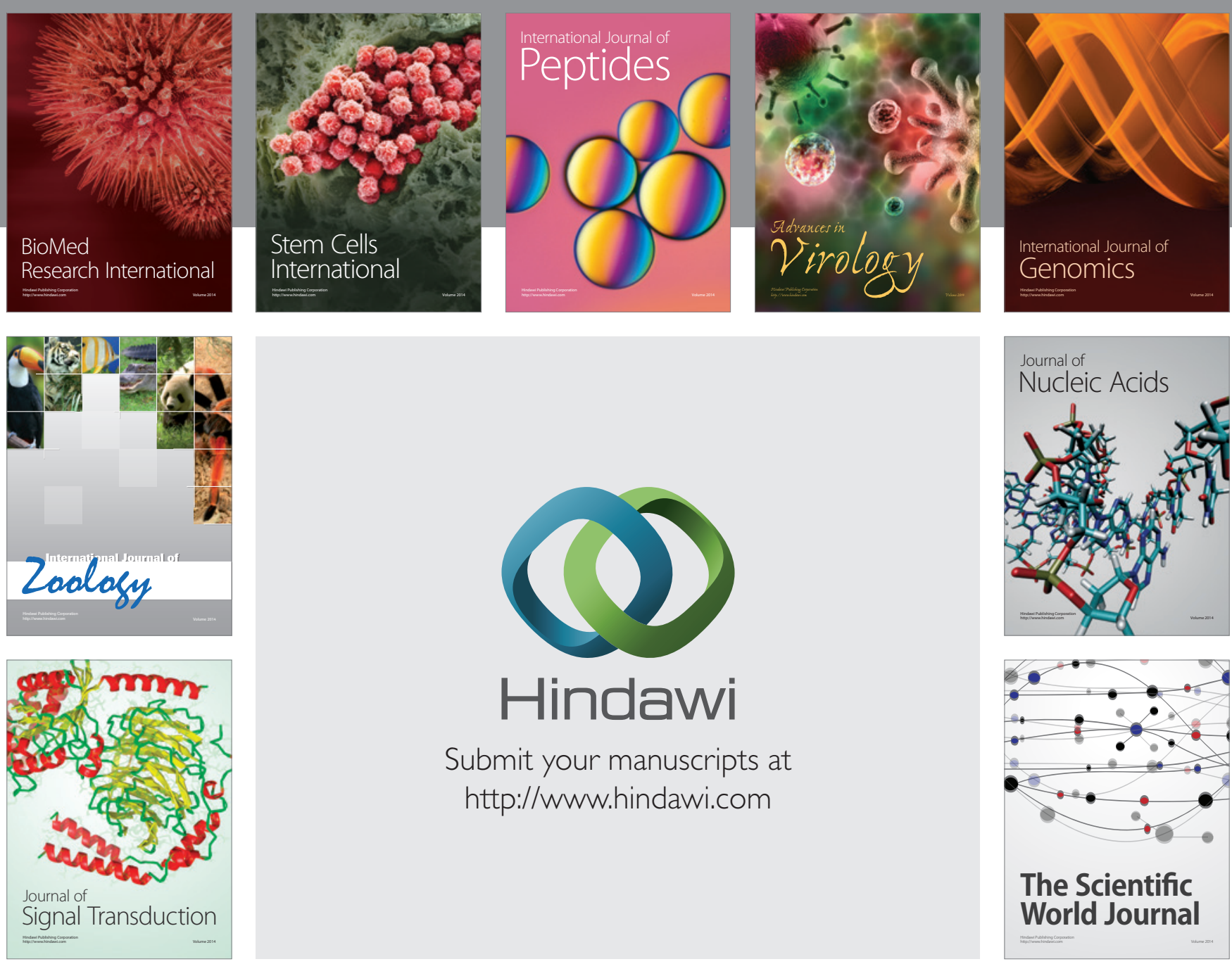

Submit your manuscripts at

http://www.hindawi.com
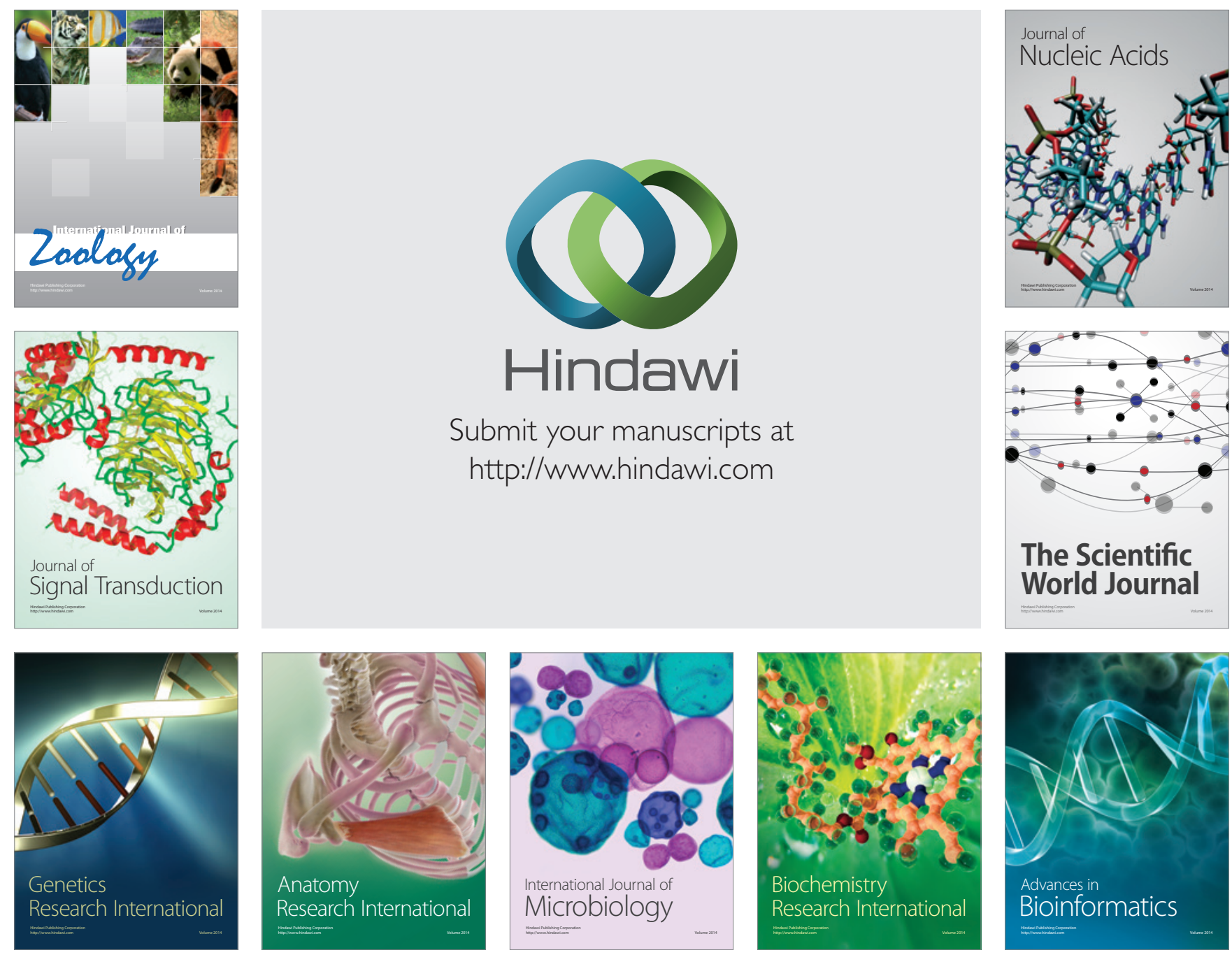

The Scientific World Journal
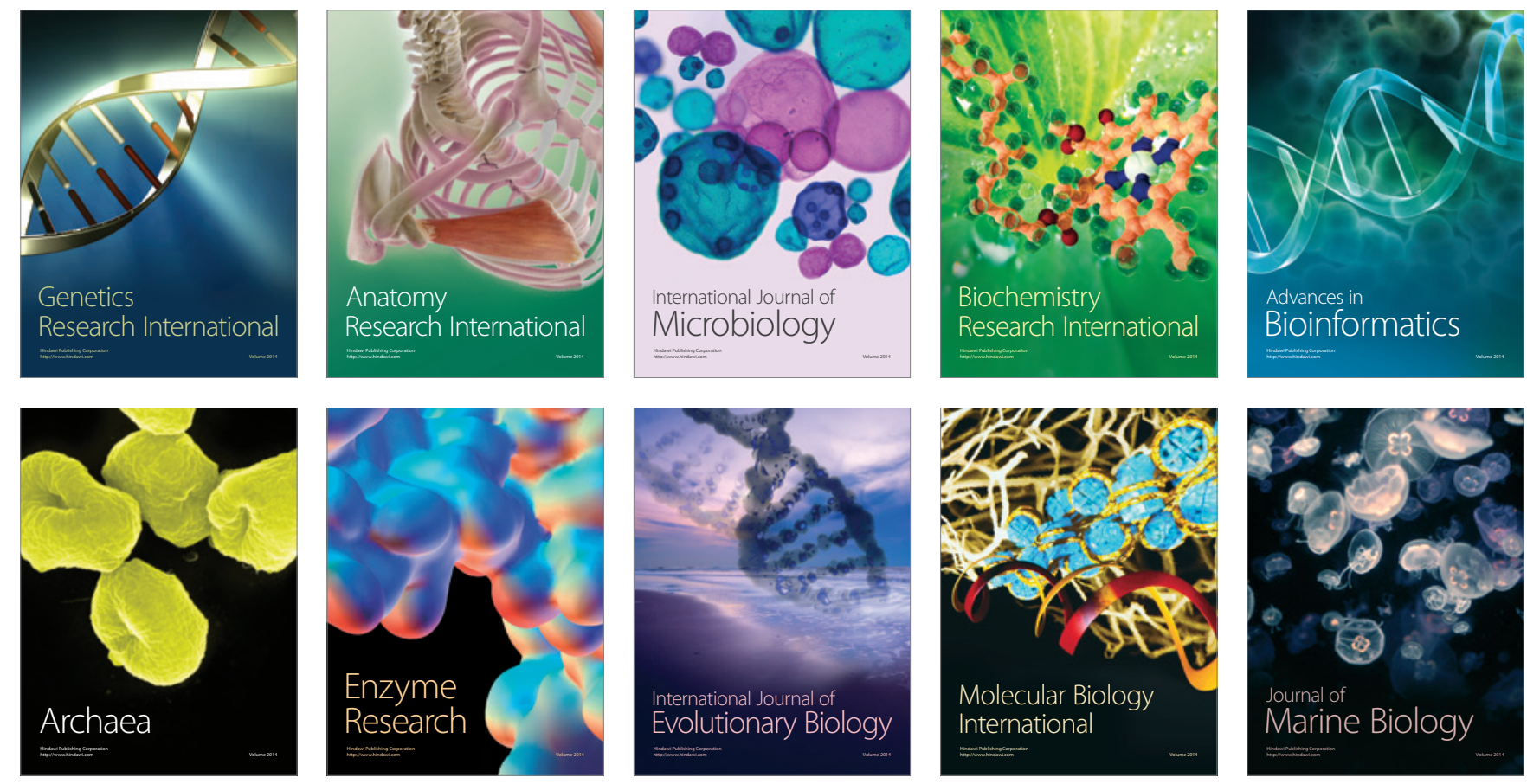